\title{
E-Marketing Orientation and Social Media Implementation in the Banking Industry in Nigeria
}

\author{
N. Gladson Nwokah, Boma Benita Irimagha \\ Department of Marketing, Faculty of Management Sciences, Rivers State University, Port Harcourt, Nigeria \\ Email: nwokah.gladson@ust.edu.ng
}

How to cite this paper: Nwokah, N.G. and Irimagha, B.B. (2017) E-Marketing Orientation and Social Media Implementation in the Banking Industry in Nigeria. iBusiness, 9, 111-133.

https://doi.org/10.4236/ib.2017.94009

Received: October 14, 2017

Accepted: December 10, 2017

Published: December 13, 2017

Copyright (c) 2017 by authors and Scientific Research Publishing Inc. This work is licensed under the Creative Commons Attribution International License (CC BY 4.0).

http://creativecommons.org/licenses/by/4.0/ (c) (i) Open Access

\begin{abstract}
The purpose of this study was to empirically investigate how E-Marketing Orientation relates with Social Media Implementation in the Banking Industry in Nigeria. Three hundred and fifty five (355) copies of the questionnaire were administered to respondents. Upon retrieval and data cleaning, 338 copies were subjected to Data analysis. Data analyses were aided by the use of SPSS version 20.0 and hypotheses were tested using the Pearson Correlation Coefficient. After the data analysis, it was revealed that: Philosophical component has a weak and positive relationship with Social Media Implementation (Business Use and Private Use). The study also revealed a moderate and positive relationship between initiation components and Business Use as a measure of Social Media Implementation but a weak and positive relationship exists between Initiation components and Private Use. Adaptation component was found to have a weak and negative relationship with Social Media Implementation measures (Business Use and Private Use). The study also revealed a strong and positive relationship between Implementation components and Business Use and a moderate and positive relationship between Implementation components as a dimension of E-Marketing Orientation and Private Use as a measure of social media implementation. We therefore concluded that there is a weak and positive relationship between Philosophical components as a dimension of E-Marketing Orientation and Social Media Implementation measures (Business Use and Private Use). Moderate and positive relationship exists between Initiation components and Business Use but a weak and positive relationship exists between Initiation component and Private Use as a measure of Social Media Implementation. Adaptation component has a weak and negative relationship with Social Media Implementation (Business Use and Private Use). Also, strong and positive relationship exists between Implementation component and Business Use as a measure of social media implementation but a
\end{abstract}


moderate and positive relationship exists between Implementation components as a dimension of E-Marketing Orientation and Private Use as a measure of social media implementation. Based on the findings and conclusions we recommended that since Philosophical component of EMO has a weak and positive relationship with Social Media Implementation (Business Use and Private Use), Banking firms in Nigeria should make it a strategic necessity to be involved in e-marketing, develop e-marketing initiatives and inform employees that success depends on the adoption of advanced e-marketing resources. Since there is a moderate and positive relationship between Initiation components and Business Use and a weak and positive relationship between Initiation components and Private Use, Banking firms in Nigeria should monitor competitors' adoption of e-marketing, carry out in-house research about e-marketing and meetings should be held regularly to prepare e-marketing plans and follow the developments in e-marketing. Also, since Adaptation component has a weak and negative relationship with Social Media Implementation, Banking firms in Nigeria should use e-marketing resources such as web site and e-mail to communicate with their customers and also conduct commercial transactions, have a computerized customer database that they can use to perform marketing activities and use e-marketing in the normal course of carrying out day-to-day business. Finally, since a strong and positive relationship exists between Implementation components and Business Use as a measure of Social Media Implementation and a moderate and positive relationship exists between Implementation components and Private Use, Banking firms in Nigeria should see that the activities of the different departments which are responsible for e-marketing implementation are well coordinated, ensuring that there is adequate technical support and also ensuring that the latest e-marketing technologies are installed in the bank.

\section{Keywords}

E-Marketing, Orientation, Social Media, Banking, Nigeria

\section{Introduction}

Scholars argue that the world economy is driven by the banking sector and that the banking activities are vital to the development of the nation. Funds intermediation is the core activity of a bank. Banks mobilize funds from the surplus units to the deficit unit, thus leads to economic growth and development. According to [1] to promote the viability and stability of the banking system in $\mathrm{Ni}$ geria, the banking sector reform was designed. It was aggravated by the necessity to proactively put the banking industry in Nigeria on the way of global competitiveness and effectively respond to the challenges of globalization. For this goal to be achieved depends on the orientation of the managers and staff of these banks. In all, in a competitive economy, for a business to succeed, it will depend on the quality and performance of the managers/employees and how market oriented they 
are. In the last twenty years activities of marketing and management have been the topic of change. Scholars like ([2] [3] [4] [5]) posited the old marketing belief appears to have lost its position. The coming out of new information and communication technologies like the Internet are changing the rules of marketing and also the market thereby weakening the position of corporate competitiveness and also presents new opportunities and individuals' empowerment [6]. Scholars like [7] argued for a marketing that is focused on relationship. They saw it as another approach to marketing. Scholars argued for a marketing that is focused on the customer based on cooperation and help customers than control the customers ([8] [9]). Thus, the need to re-define marketing approaches.

Today, social media solution has become the most recent IT-based solution. Although businesses and organizations have their own Facebook and Twitter pages, although they use social media tools to monitor the social network, many organizations have not been successful in employing these social solution. According to [10] some of the social media sites that dominate the market globally are Facebook, LinkedIn, YouTube and Twitter. The success of social media has led many researchers to study a selection of application and matter that are related to the use of social media in organizations. The researchers study the application of its role in individual adaptation to IT-induced change in organization, applications of its roles in providing e-services and application of its roles in finding business opportunities. Other researchers like [1] carried out studies on the potential problems of social media use in organizations. It includes hiring decision, privacy concerns, and also organizational productivity. Market orientation is such concept which has significant role in realization of this goal, because it focuses on collecting information about the needs and also the customers' demands and competitors capabilities in one hand, it leads to utilization and use of organizational resources and integration of units within the organization and creation of highest value for the customers on the other hand [11]. Ability of the company in utilization of market orientation policies actually depends on conditions of its employees. Higher market orientation in the organization can be concluded to cause increased group working and collective working spirit and hence increased commitment in employees of the organization. It was posited that organizational orientation framework should be considered due to lack of implementation.

For managers to bridge the social media gap in terms of its usage and sophistication, the right organizational orientation model will help. Electronic marketing was developed specifically to deal with electronic marketing and therefore it is suitable for social media implementation. Social media use and networks in the past has amazingly increased [12]. [13] posited that the success of the implementation of social media is vital to marketing effective because of the benefit and opportunities that can be derived from it. According to [14], companies that make use of social media have real competitive advantage over those that do not. He went further to say that the gap is widening between those companies. How- 
ever, in spite of its banking economic and social importance to the economy of Nigeria, at the moment it appears that little literature or none exist that I know of on E-marketing Orientation and Social Media Implementation in the Banking Industry in Nigeria. Few available literatures studied the variables with other variables. Few study the variables but in different industries and different countries like the studies of [15]. They carried out a research in Jordan and used two measures to measure E-marketing orientation. They are philosophical components and behavioural components (initiation and implementation). Also, [16] carried out a study on developing and validating the measurement scale of e-marketing orientation in New York. They measured E-marketing using cultural philosophical, initiation and system development and integration.

Furthermore, authors like [14] carried out research on Understanding Social Media in China. The authors made use of content, platforms to measure Social Media Implementation. [15] studied the social media antecedents of B2B use in industrial marketing context in Finland. They measured social media implementation using two measures. They are business use and private use. Other authors like, [16] studied E-marketing orientation and social media implementation in marketing in Australia. They used philosophical, initiation, implementation and adaptation component to address different implementation issues faced by marketers in social media implementation. From the discussion so far, it appears that there have been few studies on E-marketing Orientation ([13] [14] [15]) and also Social Media Implementation like the studies of [15] and also [16]. Despite these few, at present there is no study that I know of on the relationship between E-Marketing Orientation and Social Media Implementation in the Banking Industry in Nigeria. It is on this backdrop that this study was done to examine empirically the relationship between E-marketing Orientation and Social Media Implementation in the Banking Industry in Nigeria. EMO was conceptualized and validated as a multidimensional construct. Based on the conceptualization of EMO, it can be theoretically considered as high order formative because any changes in its components (philosophy and behavior) are expected to cause changes in its structure and dynamics [13]. Firms have come to know that the use of electronic facilities is very vital for customers and suppliers services. Firms that want to achieve higher value must stress on technological development to incorporate the needs of customer and also build up the capabilities for information search via e-Business tools. Employments for a large group of specialized skills for the citizens in a country are provided by the financial service industry [17]. However, despite the sound banking system and the importance of banks, the banking industry has experienced many changes as a consequence of technology and globalisation. Nigerian banks face rising costs, increased competition and a rapidly changing business environment which may negatively impact their performance [18]. The nexus between E-marketing Orientation and Social Media Implementation is an important one. The various dimensions of E-marketing Orientation are likely to have link with the various measures of Social Media Implementation. The problem of this research is: How do the dimensions of E-marketing 
Orientation relate with the measures of Social Media Implementation in the banking industry in Nigeria.

\section{Theoretical Foundation (Diffusion of Innovation Theory)}

The theoretical Foundation is built on the diffusion of innovation theory by Rogers in 1962 [18]. This theory proposes that diffusion of innovation is influenced by certain factors such as: "the innovation itself; time; social system and communications channels" which are all dependent in human capital [19]. In electronic marketing diffusion of innovation can be applied in the organization, via technological innovation (e.g. e-marketing), communication and social network analysis (e.g. social media analysis) [20]. In this sense, technological innovation adoption would enhance the use internet (e-marketing) on social media platform and the rate of innovation adoption irrespective of its complexity [21]. The adoption of diffusion of innovation theory in this study is informed by its relative advantage [21], perceived significance to the banking industry [22] and its demands in the contemporary society. Following the role of diffusion of innovation in internet marketing and social media implementation through technological innovation adoption, penetration of the market with new products and services is made easy [19] powered by social network of consumers, customers/potential customers alike. The diffusion of innovation emphasizes the need and use of social media network as a premise for adopter, and a wide spread of individual computer would enhance a better technological innovation. Again this theory is expected to be valuable to the banking industry especially when dealing with complexities in the turbulent marketing environment and the success of new market offerings. Understanding and application of diffusion of innovation theory in this research will help the marketer to ensure an effective discrimination of information and spread of new product/service to the consuming public. Finally it will shape the beliefs/behaviors and the orientation of adopting e-marketing in marketing organizations.

\section{Concept and Dimensions of E-Marketing Orientation (EMO)}

[15] posited that Electronic-marketing Orientation is a new projected organizational orientation. Market Orientation is different from EMO as a result of digital technology focus and also right for implementation of social media [23]. The fast growth of e-marketing and the opportunity it presents have led to the thrust for a model. The model comprises Philosophical dimension, Initiation dimension, Implementation dimension and Adoption dimension [15]. E-marketing is defined by [24] as the use of electronic media in communicating and delivering customer value that benefit the organisation. E-Marketing literature like the study of [25] is committed to electronic marketing use in transaction and payment completion, disintermediation, real-time issues in pricing, examining individual customer behaviours, and building relationship. E-marketing orientation in an 
organization shows the behavior and beliefs of the adoption of e-marketing and thus shapes interest in cyberspace. Organizations that know that achievement of success in the firm depends on e-marketing will continuously put effort in improving e-marketing activities in the organization. E-marketing is not the same as market orientation because of its use of digital technology [23]. As a result of e-marketing growth and importance a model was introduced that contains four components. They are Philosophical, Initiation, Implementation and Adoption [15].

\subsection{Philosophical Component}

Philosophical component is seen as the organisational culture and internal belief that organisation's success depends fundamentally on marketing. As [26] argued organisational culture is vital for social media to be implemented successful. When EMO function well it provides favourable environment for the organization to implement social media. Thus it enhances the significance of understanding and responding to customers.

\subsection{Initiation Components}

Initiation component is the actions taken, and not the attitudes or state of mind underlying them. These actions taken support the gathering and spreading of information and also the bringing together of functional areas. In this stage e-marketing intentions are transformed to formal and planned projects. These planned projects include activities like gathering of e-marketing information from diverse areas. It includes the evaluation of diverse alternatives of adoption and also includes adoption planning and making decision to adopt. For social media implementation to be successful information must flow from customers to the organization and also between functional areas. [20] posited that this is alike to dissemination of information and inter-functional coordination of market orientation.

\subsection{Adaptation Components}

The Adaptation component is seen as allowing and encouraging organizations employees to make use of social media. [27] stated that organisations must be ready internally and externally in order to make use of new technology. [28] agrees that the organization must be able to adopt, use, and benefit successfully from technology and innovation. [29] established that the initial adaptation of electronic marketing, organizational internal readiness is also important. The embracing of technology however relies on the supposed effectiveness of it that it increases user's performance [30].

\subsection{Implementation Components}

The Implementation component involves activities that put e-marketing into practice. It emphasizes technologies and also skills of employee. [28] posited that 
it is important for organizations to be up-to-date in their e-marketing activities so that competitors will not take over the market. The introduction of sophisticated databases, behavioural learning and also other qualitative insights can improve the quality of customer interaction through social media channels.

\section{Concept and Dimensions of Social Media Implementation}

Social media implementation is also called user-generated communication. [31] posited that social media implementation has changed company's tools and strategies they use in communicating because information control now lies with the customer. It is an online social community that facilitates ideas sharing, document publishing and video content. Platforms of social media includes social networking tools, professional networking sites media sharing sites and commerce communities sites like Facebook, Twitter, Linkedln, YouTube, Instagram and Amazon [15]. The coming on of social media has significantly altered the way people and organizations communicate. [32] posited that social media is internet based applications that is built on the ideological and technological foundations and also permits formation and exchange of user generated content. With social media firms create, share, exchange information, help shape people's connections via different social media platforms, review of their online customers and build reputation [12]. Social Media Implementation is described as online community were people share ideas and interest, circulate articles and video and other multimedia content, write reviews, buy and sell and also play games across the community e.g. Facebook, YouTube, Trip Advisor and Zyna. Social Media Implementation like the studies of [33] they measured social media implementation using micro blogging services, social networking services, location-aware mobile services and corporate discussion forum services. Furthermore, authors like [14] carried out research on Understanding Social Media in China. The authors made use of content, platforms to measure Social Media Implementation. [15] studied the Antecedents of social media B2B use in industrial marketing context in Finland. They measured social media implementation using two measures: business use and private use. [34] measured Social Media using Benefits, Clients' trust and Content.

\subsection{Private Use}

[35] posited that social media is use by most people to connect with friends and family. It is use more for private use than business use. They established that ideas of business executives' on the interaction of customers with their companies were too rosy. According to them customers were not as much eager to learn about new products and information than on receiving payback as regards their existing wants and needs. They concluded that the real application of social media is frequently motivated by individual factors. [36] posited that the personal use of social network sites aids performance as workers interact with each other through social network sites. 


\subsection{Business Use}

Social media has played an important function on the interaction of people with each other since its development. Social media has contributed a lot to the interaction of companies with their potential customers from business viewpoint. Businesses create and develop website because of its importance. Thus, social media has become a vital way organizations employ to reach their target customers because they are necessary for maintaining competitive edge and without social media networking sites organization miss many marketing opportunities. Social media is a platform where businesses work together with customers directly and the interaction aid in building strong online reputation. They are resources for businesses that want to promote and showcase their products and services online [37]. The Internet by using web-based applications permits millions of people to hook up with each other, businesses to promote their businesses in the entire world. Currently, people use advertising online than in print media, radio or television. One of the benefits of social media for businesses is that it helps businesses interact with their customers through the tweets and Facebook updates that customer post and gives the organization insight into what they need. This helps the organization devise marketing strategies that tackles customers' needs. That is, it gives customers convenient and accessible way to express their feelings and companies opening to view complaints and react to their problems. Also social media site use by businesses is free and engaging customers has no expense other than time. Companies and other organizations use social media to improve their business capacity and performance [38].

\section{E-Marketing Orientation and Social Media Implementation}

According to [13], the likely benefits of social media make social media implementation successfully vital for effective marketing strategy. Electronic marketing orientation was developed to tackle electronic marketing and thus suitable for the implementation of social media ([39] [40]). Organisations with high degrees of e-marketing orientation are likely to show high social media implementation [41].

\subsection{Philosophical Component and Social Media Implementation}

According to the findings of [12], Philosophical component aid culture and belief internally and sees social media as part of the business approach rather than simple technology and vital for the satisfaction and success of customer and organisation. [28] posited that a culture that is flexible is necessary for social media implementation. According to [28] the greater the Philosophical component of the organisation, the more the organisation will succeed with the implementation of social media. Thus, the following hypotheses were proposed.

$\mathrm{Ho}_{1}$ There is no significant relationship between Philosophical component and Private Use. 
$\mathrm{Ho}_{2}$ There is no significant relationship between Philosophical component and Business Use.

\subsection{Initiation Component and Social Media Implementation}

According to [42] the study revealed that organisation marketers said they do not even know this metric. According to them, not understanding social media will stop the ability to put social media effectively into practice. Lack of ability to make superior marketing leads to inefficiency and reduces organization marketer's intentions to effectively use social media. [40] posited that the greater the Initiation component of the organisation the more successful the organization in the implementation of social media. Thus, the following hypotheses were proposed.

$\mathrm{Ho}_{3}$ There is no significant relationship between Initiation component and Private Use.

$\mathrm{Ho}_{4}$ There is no significant relationship between Initiation component and Business Use.

\subsection{Adaptation Component and Social Media Implementation}

The Adaptation component describes employees' day-to-day use of e-marketing in carrying out their business. Its shows employees learn the right way to use social media internally to interact with the customers. [43] [44] posited that the Adaptation component would help implementing of social media effectively. Thus, the following hypotheses were proposed.

$\mathrm{Ho}_{5}$ There is no significant relationship between Adoption component and Private Use.

$\mathrm{Ho}_{6}$ There is no significant relationship between Adoption component and Business Use.

\subsection{Implementation Component and Social Media Implementation}

The Implementation component links several internal implementation activities necessary to implement social media [12]. It refers to resourcing, skills and technology capabilities for e-marketing. That is, investment in right skills and technological expertise to effectively connect with the fast growing environment of digital marketing. The fast change of the environment of electronic marketing leads to areas on to renew strategy and tactics as new social media platforms surface.

[45] in his study suggested that the greater the organisation's Implementation component, the greater the success of social media implementation. Thus, the following hypotheses were proposed.

$\mathrm{Ho}_{7}$ There is no significant relationship between Implementation component and Private Use.

$\mathrm{Ho}_{8}$ There is no significant relationship between Implementation component and Business Use. 


\section{Operational Framework}

Figure 1 depicts the researcher's operationalization of the relationships that exist amongst the variables.

\section{Methods}

This hypothesis testing study adopted a causal investigation to establish a relationship between E-Marketing and Social Media Implementation in the Banking firms in Nigeria. The study variables were not manipulated or interfered into by the researcher. The choice of research design is likely to be influenced, as [46] noted, by the nature of the study, purpose of the study, study setting and unit of analysis of the study. Considering all these, the cross sectional survey research design in a non-contrived (normal or natural) setting (banking firms) was adopted. According to [47], the survey research design offers a wide coverage and permits generalizability of research findings. The cross sectional study involves a study at a single time. The target organisation in this study is banking firms operating in the financial service sector in Nigerian economy. The twenty commercial banks licensed by CBN represent the sample of this study. The target population constitutes the 3121 staff listed in the Bankers Association of Nigeria, Rivers State Chapter. Since, our study unit is the bank employees, using the [47] sample size determination table the appropriate sample size for the population of 3121 is 388. Therefore 388 was used as sample size. For equitable distribution of the study instrument which designed in a five-point Lickert scale, anchored by strongly disagree to strongly agree, 18 copies of the questionnaire were distributed to top and middle level managers in the 20 banks in Nigeria having presence in Rivers State. A reasonable size of 355 copies of the questionnaire were retrieved and used in the study. Both descriptive and inferential statistics were used for data analysis. The Pearson Moment Correlation was used to test the state hypotheses after examining the normality test which showed a normal curve.

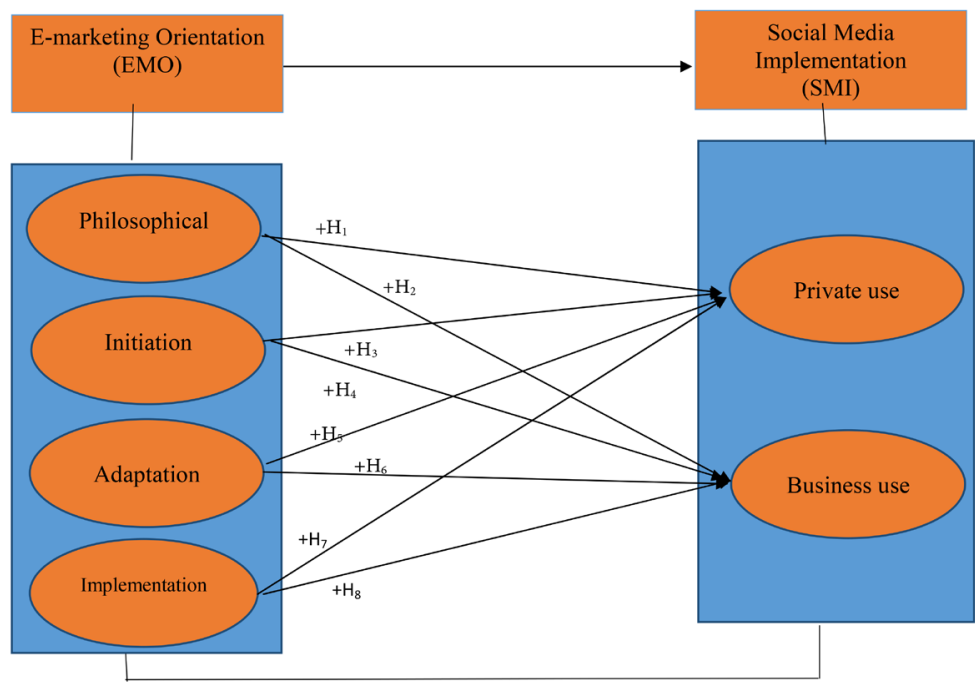

Figure 1. Operational framework on the relationship between e-marketing orientation and social media implementation of banking firms in Nigeria. 


\section{Illustration of Findings}

\subsection{Reliability and Validity of Research Instrument}

[47] posited that, it is vital to make sure that adequate reliability and validity test is carried out on the research instrument. [48] defined reliability as the consistency of an instrument when measured repeatedly. [45] posited that validity is when an instrument measures what it is meant to measure. The research instrument was administered on senior academics within Rivers State University for vetting. Upon collection the final questionnaire was drawn. According to [46], the Cronbach Alpha Coefficient from the Statistical Package of Social Sciences is a good reliability coefficient that shows how questionnaire items are interrelated. Thus, it was also used to test the reliability of our research instrument. See Table 1.

The instrument with the aid of SPSS revealed a very high reliability coefficient for the two tested variables. The results in Table 1 falls within the standard range of 0.7 set by [45]. The table shows 12 items were used to measure E-Marketing Orientation and the Cronbach's Alpha co-efficient recorded 0.9 meaning there is a correlation amongst the items hence, reliable. 4 items were used to measure Social Media Implementation and this was found to be reliable with Cronbach's Alpha co-efficient of 0.9 meaning there is a very strong correlation amongst the items in our questionnaire.

\subsection{Findings from the Descriptive Statistics}

\subsubsection{Philosophical as a Dimension of E-Marketing Orientation}

The items of the dimensions of e-marketing orientation are assessed with the mean and standard deviations. Table 2 shows philosophical dimensions of e-marketing orientation.

As can be seen in Table 2, it appears that bank encourages the growth of e-marketing initiatives in their business. This is evident as the statistical evidence shown in Table 2 indicates that banks encouragement in the development of e-marketing initiatives has the highest mean of 4.30 with a standard deviation of 0.817 . This is closely followed by the banks deem it necessary to be involved in e-marketing as a fundamental for organizations' success with the mean of 4.23 and the standard deviation of 0.836 .

\subsubsection{Initiation as a Dimension of E-Marketing Orientation}

Initiation as a dimension of e-marketing orientation is assessed with the mean and standard deviations. Table 3 shows initiation as dimensions of e-marketing orientation.

Table 1. Reliability test results.

\begin{tabular}{cccc}
\hline S/NO. & Variables & Number of Items & Cronbach's Alpha \\
\hline 1 & E-Marketing Orientation (EMO) & 12 & 0.9 \\
2 & Social Media Implementation (SMI) & 4 & 0.9 \\
\hline
\end{tabular}

Source: SPSS Output. 
Table 2. Philosophical as a dimension of e-marketing orientation.

\begin{tabular}{rlcc}
\hline S/NO & \multicolumn{1}{c}{ Philosophical Component } & Mean _ $\chi$ & Std Dev s \\
\hline 1 & $\begin{array}{l}\text { Our bank deems it necessary to be involved in e-marketing as a } \\
\text { fundamental for organization's success. }\end{array}$ & 4.23 & 0.658 \\
$2 \quad \begin{array}{l}\text { Our bank encourages the development of e-marketing } \\
\text { initiatives. }\end{array}$ & 4.30 & 0.817 \\
$3 \quad \begin{array}{l}\text { Employees are told that to succeed depends on e-marketing } \\
\text { adoption. }\end{array}$ & 3.78 & 0.836 \\
\hline
\end{tabular}

Source: SPSS Output. KEY: $\_\chi=$ Mean score, $s=$ Standard deviation.

Table 3. Initiation as a dimension of e-marketing orientation.

\begin{tabular}{|c|c|c|c|}
\hline S/NO & Initiation Component & Mean_X & Std Dev s \\
\hline 1 & $\begin{array}{l}\text { Our bank monitors the adoption of e-marketing by } \\
\text { competitors'. }\end{array}$ & 3.78 & 0.836 \\
\hline 2 & Our bank does in-house e-marketing research. & 3.51 & 1.128 \\
\hline 3 & $\begin{array}{l}\text { Our bank holds meetings yearly to prepare e-marketing plans } \\
\text { and also follow its developments using several secondary } \\
\text { sources. }\end{array}$ & 3.40 & 1.241 \\
\hline
\end{tabular}

Source: SPSS Output.

As can be seen in Table 3, it appears that bank encourages the monitoring of the adoption of e-marketing by competitors'. This is evident as the statistical evidence shown in Table 3 indicates that banks encourages the monitoring of competitors' adoption of e-marketing orientations has the highest mean of 3.78 with a standard deviation of 0.836 . This is closely followed by the banks in-house research activities about e-marketing with the mean of 3.51 and the standard deviation of 1.128

\subsubsection{Adaptation as a Dimension of E-Marketing Orientation}

Adoption as a dimension of e-marketing orientation is assessed with the mean and standard deviations. Table 4 shows adaptation as a dimension of e-marketing orientation.

As can be seen in Table 4, it appears that bank use computerized customer to perform marketing activities appears to account the highest indicator of adaptation. This is evident as the statistical evidence shown in Table 4 indicates that banks use computerized customer to perform marketing has the highest mean of 3.93 with a standard deviation of 1.438 . This is closely followed by the bank employees in carrying out their day-to-day business make use of e-marketing with the mean of 3.62 and the standard deviation of 0.809 .

\subsubsection{Implementation as a Dimension of E-Marketing Orientation}

Implementation as a dimension of e-marketing orientation is assessed with the mean and standard deviations. Table 5 shows implementation as a dimension of e-marketing orientation.

As can be seen in Table 5, installation of the latest e-marketing in Nigeria banks appears to account the highest indicator of implementation. This is evident as the statistical evidence shown in Table 4. 5 indicates that the installation 
Table 4. Adaptation as a dimension of e-marketing orientation.

\begin{tabular}{rlcc}
\hline S/NO & \multicolumn{1}{c}{ Adaptation Component } & Mean_X & Std Dev s \\
\hline $1 \quad \begin{array}{l}\text { In the bank, e-marketing resources are used to communicate } \\
\text { with customers and also conduct commercial transactions. }\end{array}$ & 2.89 & 0.986 \\
$2 \quad \begin{array}{l}\text { The bank use computerized customer database to perform } \\
\text { marketing activities. }\end{array}$ & 3.93 & 1.438 \\
$\quad \begin{array}{l}\text { The bank employees in carrying out their day-to-day business } \\
\text { make use of e-marketing. }\end{array}$ & 3.62 & 0.809 \\
\hline
\end{tabular}

Source: SPSS Output.

Table 5. Implementation as a dimension of e-marketing orientation.

\begin{tabular}{clcc}
\hline S/NO & \multicolumn{1}{c}{ Implementation Component } & Mean _X & Std Dev s \\
\hline 1 & $\begin{array}{l}\text { In our bank, there is proper coordination of the activities of the } \\
\text { different departments. }\end{array}$ & 3.03 & 0.869 \\
2 & In our bank, there is adequate technical support. & 3.95 & 0.673 \\
3 & Our bank has the latest e-marketing technologies installed. & 4.18 & 1.032 \\
\hline
\end{tabular}

Source: SPSS Output.

of latest e-marketing technologies has the highest mean value of 4.18 with a standard deviation of 1.032. This is closely followed by the availability of adequate technologies or web applications in the Nigeria banking sector with the mean of 3.95 and the standard deviation of 0.673 .

\subsubsection{Private Use as a Measure of Social Media Implementation}

The indices to measure the dependent variables (Social media) were also assessed. Private use as a measure of social media implementation was measured with two items.

As can be seen in Table 6, bank employees engage in social media for the purpose of connecting with friends and family which off course accounts to the highest indicator of Private Use as a measure of Social Media Implementation. This is evident as the statistical evidence shown in Table 6 indicates that Private Use as a measure of Social Media Implementation mean value of 3.72 with a standard deviation of 0.918 .

\subsubsection{Business Use as a Measure of Social Media Implementation}

Business use as a measure of social media implementation was measured with two items. Table 7 shows the mean and standard deviation of the two items.

As can be seen in Table 7, bank employees engage in social media to help increase brand awareness and further used to boost sales accounts as the highest indicator of Business Use as a measure of Social Media Implementation. This is evident as the statistical evidence shown in Table 7 indicates that Private Use as a measure of Social Media Implementation has mean value of 2.98 with a standard deviation of 1.129 .

\subsection{Testing of Research Hypotheses}

This section is aimed at testing the eight hypotheses of this study. Since the descriptive analysis showed normal distribution of both variables, to run the parametric analysis we made use of the Pearson moment correlation. 
Table 6. Private use as a measure of social media implementation.

\begin{tabular}{clcc}
\hline S/NO & \multicolumn{1}{c}{ Private Use } & Mean $\_$ & Std Dev s \\
\hline $1 \quad \begin{array}{l}\text { Our bank employees engage in social media for the reason of } \\
\text { connecting with friends and family. }\end{array}$ & 3.72 & 0.918 \\
$\quad \begin{array}{l}\text { Our bank employees engage in social media and this affects } \\
\text { their work performance negatively. }\end{array}$ & 3.20 & 1.228 \\
\hline
\end{tabular}

Source: SPSS Output.

Table 7. Business use as a measure of social media implementation.

\begin{tabular}{clcc}
\hline S/NO & \multicolumn{1}{c}{ Business Use } & Mean $\_$ & Std Dev s \\
\hline 1 & $\begin{array}{l}\text { Our bank employees engage in social media to help increase } \\
\text { brand awareness and further used to boost sales. }\end{array}$ & 2.98 & 1.129 \\
2 & $\begin{array}{l}\text { My work as an employee has improved since the introduction of } \\
\text { the tool. }\end{array}$ & 2.55 & 0.801 \\
\hline
\end{tabular}

Source: SPSS Output.

\subsubsection{Relationship between Philosophical Component and Private Use}

This study hypothesized that there is no significant relationship between Philosophical component and Private use. Table 8 shows the statistical evidence of the relationship between these dimensions.

The statistical evidence in Table 8 suggests a weak and positive relationship between Philosophical as a dimension of E-Marketing Orientation and Private Use as a measure of social media implementation with 0.238 Pearson correlation coefficient at 0.01 significant levels. This does not support hypothesis one $\left(\mathrm{H}_{1}\right)$, that there is no relationship between Philosophical as a dimension of E-Marketing Orientation and Private Use as a measure of Social Media Implementation.

\subsubsection{Relationship between Philosophical Component and Business Use}

This study hypothesized that there is no significant relationship between Philosophical component and Business use.

The statistical evidence in Table 9 suggests a weak and positive relationship between Philosophical as a dimension of E-Marketing Orientation and Private Use as a measure of Social Media Implementation with 0.216 Pearson correlation coefficient at 0.01 significant levels. This does not support hypothesis two $\left(\mathrm{H}_{2}\right)$, that there is no relationship between Philosophical as a dimension of E-Marketing Orientation and Private Use as a measure of Social Media Implementation.

\subsubsection{Relationship between Initiation Component and Private Use}

This study hypothesized that there is no significant relationship between Initiation component and Business use.

The statistical evidence in Table 10 suggests a weak and positive relationship between Initiation components as a dimension of E-Marketing Orientation and Private Use as a measure of social media implementation with 0.195 Pearson correlation coefficient at 0.01 significant levels. This does not support hypothesis three $\left(\mathrm{H}_{3}\right)$, that there is no relationship between initiation components as a dimension of E-Marketing Orientation and Private Use as a measure of Social Media Implementation. 
Table 8. Philosophical as a dimension of e-marketing orientation and private use $(\mathrm{n}=$ 355).

\begin{tabular}{cccc}
\hline Variables & & $\begin{array}{c}\text { Philosophical as a } \\
\text { Dimension of } \\
\text { E-Marketing } \\
\text { Orientation }\end{array}$ & $\begin{array}{c}\text { Private Use as a } \\
\text { Measure of Social } \\
\text { Media } \\
\text { Implementation }\end{array}$ \\
\hline $\begin{array}{c}\text { Philosophical as a Dimension } \\
\text { of E-Marketing Orientation }\end{array}$ & $\begin{array}{c}\text { Pearson Correlation } \\
\text { Sig. (2-tailed) }\end{array}$ & 1 & $0.238^{* *}$ \\
$\begin{array}{c}\text { Private Use as a Measure of } \\
\text { Social Media Implementation }\end{array}$ & $\begin{array}{c}\text { Pearson Correlation } \\
\text { Sig. (2-tailed) }\end{array}$ & $0.238^{\star *}$ & 0.00 \\
\hline
\end{tabular}

${ }^{* *}$ : Correlation is significant at the 0.01 level (2-tailed).

Table 9. Philosophical as a dimension of e-marketing orientation and business use $(\mathrm{n}=$ $355)$.

\begin{tabular}{cccc}
\hline Variables & & $\begin{array}{c}\text { Philosophical as a } \\
\text { Dimension of } \\
\text { E-Marketing } \\
\text { Orientation }\end{array}$ & $\begin{array}{c}\text { Business Use as a } \\
\text { Measure of Social } \\
\text { Media }\end{array}$ \\
$\begin{array}{ccc}\text { Philosophical as a Dimension } \\
\text { of E-Marketing Orientation }\end{array}$ & $\begin{array}{c}\text { Pearson Correlation } \\
\text { Sig. (2-tailed) }\end{array}$ & 1 & $0.216^{\star *}$ \\
$\begin{array}{c}\text { Business Use as a Measure of } \\
\text { Social Media Implementation }\end{array}$ & $\begin{array}{c}\text { Pearson Correlation } \\
\text { Sig. (2-tailed) }\end{array}$ & $0.216^{* *}$ & 0.00 \\
\hline
\end{tabular}

**: Correlation is significant at the 0.01 level (2-tailed).

Table 10. Initiation component as a dimension of e-marketing orientation and private use $(\mathrm{n}=355)$.

\begin{tabular}{cccc}
\hline Variables & & $\begin{array}{c}\text { Initiation Component } \\
\text { as a Dimension of } \\
\text { E-Marketing } \\
\text { Orientation }\end{array}$ & $\begin{array}{c}\text { Private Use as a } \\
\text { Measure of Social } \\
\text { Media } \\
\text { Implementation }\end{array}$ \\
\hline $\begin{array}{c}\text { Initiation Component as a } \\
\text { Dimension of E-Marketing } \\
\text { Orientation }\end{array}$ & $\begin{array}{c}\text { Pearson Correlation } \\
\text { Sig. (2-tailed) }\end{array}$ & 1 & $0.195^{\star *}$ \\
$\begin{array}{c}\text { Private Use as a Measure of } \\
\text { Social Media Implementation }\end{array}$ & $\begin{array}{c}\text { Pearson Correlation } \\
\text { Sig. (2-tailed) }\end{array}$ & $0.195^{* *}$ & 0.00 \\
\hline
\end{tabular}

**: Correlation is significant at the 0.00 level (2-tailed).

\subsubsection{Relationship between Initiation Component and Business Use}

This study hypothesized that there is no significant relationship between Initiation component and Business use.

The statistical evidence in Table 11 suggests a moderate and positive relationship between Initiation components as a dimension of E-Marketing Orientation and Business Use as a measure of social media implementation with 0.321 Pearson correlation coefficient at 0.01 significant levels. This does not support hypothesis four $\left(\mathrm{H}_{4}\right)$, that there is no relationship between initiation components as a dimension of E-Marketing Orientation and Business Use as a measure of Social Media Implementation. 
Table 11. Initiation component as a dimension of e-marketing orientation and business use $(\mathrm{n}=355)$.

\begin{tabular}{cccc}
\hline Variables & & $\begin{array}{c}\text { Initiation Component } \\
\text { as a Dimension of } \\
\text { E-Marketing } \\
\text { Orientation }\end{array}$ & $\begin{array}{c}\text { Business Use as a } \\
\text { Measure of Social } \\
\text { Media Implementation }\end{array}$ \\
\hline $\begin{array}{c}\text { Initiation Component as a } \\
\text { Dimension of E-Marketing } \\
\text { Orientation }\end{array}$ & $\begin{array}{c}\text { Pearson Correlation } \\
\text { Sig. (2-tailed) }\end{array}$ & 1 & $0.321^{* *}$ \\
$\begin{array}{c}\text { Business Use as a Measure } \\
\text { of Social Media } \\
\text { Implementation }\end{array}$ & $\begin{array}{c}\text { Pearson Correlation } \\
\text { Sig. (2-tailed) }\end{array}$ & $\begin{array}{c}0.321^{* *} \\
0.00\end{array}$ & 1 \\
\hline
\end{tabular}

**: Correlation is significant at the 0.00 level (2-tailed).

\subsubsection{Relationship between Adaptation Component and Private Use}

This study hypothesized that there is no significant relationship between Adaptation component and Private use.

The statistical evidence in Table 12 suggests a weak and negative relationship between Adaptation components as a dimension of E-Marketing Orientation and Private Use as a measure of social media implementation with -0.113 Pearson correlation coefficient at 0.01 significant levels. This again does not support hypothesis five $\left(\mathrm{H}_{5}\right)$, that there is no relationship between adaptation components as a dimension of E-Marketing Orientation and private use as a measure of Social Media Implementation.

\subsubsection{Relationship between Adaptation Component and Business Use}

This study hypothesized that there is no significant relationship between Adaptation component and Business use.

The statistical evidence in Table 13 suggests a weak and negative relationship between Adaptation components as a dimension of E-Marketing Orientation and Business Use as a measure of social media implementation with -0.197 Pearson correlation coefficient at 0.01 significant levels. This again does not support hypothesis six $\left(\mathrm{H}_{6}\right)$, that there is no relationship between adaptation components as a dimension of E-Marketing Orientation and Business Use as a measure of Social Media Implementation.

\subsubsection{Relationship between Implementation Component and Private Use}

This study hypothesized that there is no significant relationship between Implementation component and Private use.

The statistical evidence in Table 14 suggests a Moderate and positive relationship between Implementation components as a dimension of E-Marketing Orientation and Private Use as a measure of social media implementation with 0.436 Pearson correlation coefficient at 0.01 significant levels. This again does not support hypothesis seven $\left(\mathrm{H}_{7}\right)$, that there is no relationship between implementation components as a dimension of E-Marketing Orientation and Private Use as a measure of Social Media Implementation. 
Table 12. Adaptation component as a dimension of e-marketing orientation and private use $(n=355)$.

\begin{tabular}{|c|c|c|c|}
\hline Variables & & $\begin{array}{c}\text { Adaptation as a } \\
\text { Dimension of } \\
\text { E-Marketing } \\
\text { Orientation }\end{array}$ & $\begin{array}{c}\text { Private Use as a } \\
\text { Measure of Social } \\
\text { Media Implementation }\end{array}$ \\
\hline $\begin{array}{l}\text { Adaptation Component as } \\
\text { a Dimension of } \\
\text { E-Marketing Orientation }\end{array}$ & $\begin{array}{l}\text { Pearson Correlation } \\
\text { Sig. (2-tailed) }\end{array}$ & 1 & $\begin{array}{c}-0.113^{* *} \\
0.00\end{array}$ \\
\hline $\begin{array}{c}\text { Private Use as a Measure } \\
\text { of Social Media } \\
\text { Implementation }\end{array}$ & $\begin{array}{l}\text { Pearson Correlation } \\
\text { Sig. (2-tailed) }\end{array}$ & $\begin{array}{c}-0.113^{\star *} \\
0.00\end{array}$ & 1 \\
\hline
\end{tabular}

$* *$ : Correlation is significant at the 0.00 level (2-tailed).

Table 13. Adaptation component as a dimension of e-marketing orientation and business use $(n=355)$.

\begin{tabular}{|c|c|c|c|}
\hline Variables & & $\begin{array}{c}\text { Adaptation as a } \\
\text { Dimension of } \\
\text { E-Marketing } \\
\text { Orientation }\end{array}$ & $\begin{array}{c}\text { Business Use as a } \\
\text { Measure of Social } \\
\text { Media Implementation }\end{array}$ \\
\hline $\begin{array}{l}\text { Adaptation Component as } \\
\text { a Dimension of } \\
\text { E-Marketing Orientation }\end{array}$ & $\begin{array}{c}\text { Pearson Correlation } \\
\text { Sig. (2-tailed) }\end{array}$ & 1 & $\begin{array}{c}-0.197^{\star *} \\
0.00\end{array}$ \\
\hline $\begin{array}{c}\text { Business Use as a Measure } \\
\text { of Social Media } \\
\text { Implementation }\end{array}$ & $\begin{array}{c}\text { Pearson Correlation } \\
\text { Sig. (2-tailed) }\end{array}$ & $\begin{array}{c}-0.197^{\star *} \\
0.00\end{array}$ & 1 \\
\hline
\end{tabular}

$* *$ : Correlation is significant at the 0.00 level (2-tailed).

Table 14. Implementation component as a dimension of e-marketing orientation and private use $(\mathrm{n}=355)$.

\begin{tabular}{|c|c|c|c|}
\hline Variables & & $\begin{array}{c}\text { Implementation as a } \\
\text { Dimension of } \\
\text { E-Marketing } \\
\text { Orientation }\end{array}$ & $\begin{array}{c}\text { Private Use as a } \\
\text { Measure of Social } \\
\text { Media Implementation }\end{array}$ \\
\hline $\begin{array}{l}\text { Implementation Component } \\
\text { as a Dimension of } \\
\text { E-Marketing Orientation }\end{array}$ & $\begin{array}{l}\text { Pearson Correlation } \\
\text { Sig. (2-tailed) }\end{array}$ & 1 & $\begin{array}{c}0.436^{* *} \\
0.00\end{array}$ \\
\hline $\begin{array}{c}\text { Private Use as a Measure of } \\
\text { Social Media } \\
\text { Implementation }\end{array}$ & $\begin{array}{c}\text { Pearson Correlation } \\
\text { Sig. (2-tailed) }\end{array}$ & $\begin{array}{c}0.436^{\star *} \\
0.00\end{array}$ & 1 \\
\hline
\end{tabular}

**: Correlation is significant at the 0.00 level (2-tailed).

\subsubsection{Relationship between Implementation Component and Business Use}

This study hypothesized that there is no significant relationship between Implementation component and Business use.

The statistical evidence in Table 15 suggests a strong and positive relationship between Implementation components as a dimension of E-Marketing Orientation and Business Use as a measure of social media implementation with 0.606 Pearson correlation coefficient at 0.01 significant levels. This again does not support hypothesis eight $\left(\mathrm{H}_{8}\right)$, that there is no relationship between implementation 
Table 15. Implementation component as a dimension of e-marketing orientation and business use $(n=355)$.

\begin{tabular}{cccc}
\hline Variables & & $\begin{array}{c}\text { Implementation as a } \\
\text { Dimension of } \\
\text { E-Marketing } \\
\text { Orientation }\end{array}$ & $\begin{array}{c}\text { Business Use as a } \\
\text { Measure of Social } \\
\text { Media } \\
\text { Implementation }\end{array}$ \\
\hline $\begin{array}{c}\text { Implementation Component } \begin{array}{c}\text { as a Dimension of } \\
\text { E-Marketing Orientation }\end{array} \\
\text { Business Use as a Measure of }\end{array}$ & $\begin{array}{c}\text { Pearson Correlation } \\
\text { Sig. (2-tailed) }\end{array}$ & 1 & $0.606^{* *}$ \\
Social Media Implementation & Sig. (2-tailed) & $0.606^{* *}$ & .00 \\
\hline
\end{tabular}

${ }^{* *}$ : Correlation is significant at the 0.00 level (2-tailed).

components as a dimension of E-Marketing Orientation and Business Use as a measure of Social Media Implementation.

\section{New Findings}

The new findings in this study include:

1) Philosophical component has a weak and positive relationship with Social Media Implementation (Business Use and Private Use).

2) The study also revealed a moderate and positive relationship between initiation components as a dimension of E-Marketing Orientation and Business Use as a measure of Social Media Implementation. Also, a weak and positive relationship exists between Initiation components as a dimension of E-Marketing Orientation and Private Use as a measure of Social Media Implementation.

3) Adaptation component as a dimension of E-Marketing Orientation was found to have a weak and negative relationship with Social Media Implementation measures like Business Use and Private Use.

4) The study also revealed a strong and positive relationship between Implementation components as a dimension of E-Marketing Orientation and Business Use as a measure of social media implementation. There also exist a moderate and positive relationship between Implementation components as a dimension of E-Marketing Orientation and Private Use as a measure of social media implementation.

\section{Conclusions}

Based on the study findings, the following conclusions were drawn:

1) There is a weak and positive relationship between Philosophical components as a dimension of E-Marketing Orientation and Social Media Implementation in terms of Business Use and Private Use.

2) Moderate and positive relationship exists between Initiation components as a dimension of E-Marketing Orientation and Business Use as a measure of Social Media Implementation. Also, there is a weak and positive relationship between Initiation components as a dimension of E-Marketing Orientation and Private Use 
as a measure of Social Media Implementation.

3) Adaptation component has a weak and negative relationship with Social $\mathrm{Me}$ dia Implementation (Business Use and Private Use).

4) Strong and positive relationship exists between Implementation components as a dimension of E-Marketing Orientation and Business Use as a measure of social media implementation. Also moderate and positive relationship exists between Implementation components as a dimension of E-Marketing Orientation and Private Use as a measure of social media implementation.

\section{Recommendations}

The following recommendations were made based on the findings and conclusions of this study:

1) Since Philosophical components of EMO has a weak and positive relationship with Social Media Implementation in terms of Business Use and Private Use, Banking firms in Nigeria should see and make it a strategic necessity to be involved in e-marketing, develop e-marketing initiatives and inform employees that success depends on the adoption of advanced e-marketing resources.

2) Since there is a moderate and positive relationship between Initiation components and Business Use and also a weak and positive relationship between Initiation components and Private Use, Banking firms in Nigeria should monitor competitors' adoption of e-marketing, carry out in-house research about e-marketing and meetings should be held regularly to prepare e-marketing plans and follow the developments in e-marketing.

3) Also, since Adaptation component has a weak and negative relationship with Social Media Implementation Banking firms in Nigeria should use e-marketing resources such as web site and e-mail to communicate with their customers and also conduct commercial transactions. They should have a computerized customer database that they can use to perform marketing activities and should use e-marketing in the normal course of carrying out day-to-day business.

4) Finally, since a strong and positive relationship exists between Implementation components as a dimension of E-Marketing Orientation and Business Use as a measure of Social Media Implementation and also a moderate and positive relationship between Implementation components and Private Use, Banking firms in Nigeria should see that the activities of the different departments which are responsible for e-marketing implementation are well coordinated, ensure there is adequate technical support and also ensure that the latest e-marketing technologies are installed in bank.

\section{Contribution to Knowledge}

There have been several studies on E-marketing Orientation and Social Media Implementation but none that I know of have written on E-marketing Orientation and Social Media Implementation of Banking Firms in Nigeria. The present study fills this void by analyzing E-marketing Orientation and Social Media Implementation of Nigerian Banking firms. 
The researcher proposes a model of the relationship between E-marketing Orientation and Social Media Implementation of Banking firms in Nigeria based on the findings from this study, as shown in Figure 2. This model proposes that there is Strong, Moderate, Weak and Negative relationship between E-marketing Orientation and Social Media Implementation.

\section{Heuristic Model}

Figure 2 depicts the Heuristic model of the relationships that exist amongst the variables.

The Philosophical components dimension of E-marketing Orientation has a weak relationship with Social Media Implementation measures (private use and business use) of banking firms in Nigeria. The broken (dotted) arrow indicates weakness of relationship. Also, the Initiation components has a moderate and positive relationship with Business Use as a measure of Social Media Implementation as depicted by the blue arrow and also a weak and positive relationship between Initiation components as a dimension of E-Marketing Orientation and Private Use as a measure of Social Media Implementation as depicted by the broken arrow. Adaptation component has a weak and negative relationship with the two measures of Social Media Implementation as shown by the dotted arrow. Finally, a strong and positive relationship exists between Implementation components as a dimension of E-Marketing Orientation and Business Use as a measure of social media implementation as indicated by the pink arrow. Also a moderate and positive relationship between Implementation components as a dimension of E-Marketing Orientation and Private Use as a measure of social media implementation as indicated by the blue arrow.

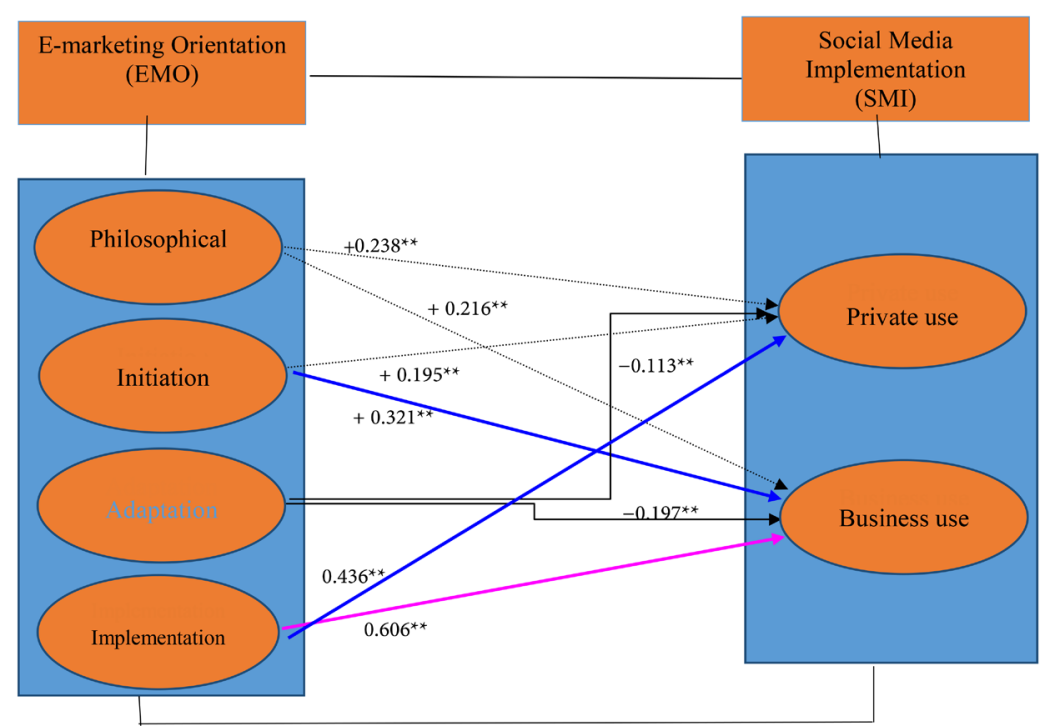

Figure 2. Heuristic model of e-marketing orientation and social media implementation of banking firms in Nigeria. $\longrightarrow:$ Strong relationship; $\longrightarrow$ : Moderate relationship; $----\rightarrow$ : Weak relationship; $\longrightarrow$ : Negative relationship. Source: Desk research, 2017. 


\section{References}

[1] Soludo, C.C. (2004) Key Address Delivered at Special Meeting of Bankers Committee at Abuja.

[2] Chaffey, D., Mayer, R., Johnston, K. and Ellis-Chadwick, F. (2000) Internet Marketing, Strategy, Implementation and Practice. FT/Prentice Hall.

[3] Coviello, N.E. and Brodie, R.J. (2001) Contemporary Marketing Practices of Consumer and Business-to-Business Firms: How Different Are They? The Journal of Business and Industrial Marketing, 16, 382-400. https://doi.org/10.1108/08858620110400223

[4] Constantinides, E. (2006) The Marketing Mix Revisited: Towards the 21st Century Marketing. Journal of Marketing Management, 22, 407-438.

https://doi.org/10.1362/026725706776861190

[5] Court, D. (2007) The Evolving Role of the CMO. The McKinsey Quarterly. http://www.mckinseyquarterly.com/The_evolving_role_of_the_CMO_2031

[6] Urban, G. (2005) Don't Just Relate-Advocate: A Blueprint for Profit in the Era of Customer Power. Wharton School Publishing.

[7] Gummesson, E. (2008) Customer Centricity: Reality or a Wild Goose Chase? European Business Review, 20, 315-330. https://doi.org/10.1108/09555340810886594

[8] Heaton, T. (2006) TV News in a Postmodern World: New Metrics and Principles.

[9] Thomas, A.R. (2007) The End of Mass Marketing: Or, Why All Successful Marketing Is Now Direct Marketing. Direct Marketing. An International Journal, 1, 6-16. https://doi.org/10.1108/17505930710734107

[10] Chong, A.Y.L., Keng-Boon, O., Lin, B. and Shu Yi, T. (2009) Influence of Interorganisational Relationships on SMEs' E-Business Adoption. Internet Research, 19, 313-331. https://doi.org/10.1108/17505930710734107

[11] Awwad, M. and Agti, D. (2011) The Impact of Internal Marketing on Commercial Banks' Market Orientation. International Journal of Bank Marketing, 29, 308-332. https://doi.org/10.1108/02652321111145943

[12] Hanna, R., Rohm, A. and Crittenden, V.L. (2011) We're All Connected: The Power of the Social Media Ecosystem. Business Horizons, 54, 265-273. https://doi.org/10.1016/j.bushor.2011.01.007

[13] Barnes, N.G. (2010) Tweeting and Blogging to the Top. Marketing Research, 22, 8-13.

[14] Chiu, C., Ip, C. and Silverman, A. (2012) Understanding Social Media in China. McKinsey Quarterly.

[15] Chen, Y. and Huang, H. (2016) Rediscovering the Essentiality of Marketing. Developing and Validating the Measurement Scale of e-Marketing Orientation. Springer International Publishing, New York.

[16] Fatemeh, H., Hamilton, C.A., Valos, M.J. and Callaghan, M. (2015) E-Marketing Orientation and Social Media Implementation in B2B Marketing. European Business Review, 27, 638-655. https://doi.org/10.1108/EBR-03-2015-0026

[17] Financial Services Sector Assessment Report (2014) Department of Economic Development. Western Cape Government.

[18] Agbolade, O.K. (2011) Information and Communication Technology and Banks Profitability in Nigeria. Australian Journal of Business and Management Research, 1, 102-107.

[19] Rogers, E. (2003) Diffusion of Innovations. 5th Edition, Simon and Schuster, New York. 
[20] Easley, D. and Kleinberg, J. (2010) Networks, Crowds and Markets: Reasoning about a Highly Connected World. Cambridge University Press, Cambridge. https://doi.org/10.1017/CBO9780511761942

[21] Tan, K.S., Chong, S.C., Lin, B. and Eze, U.C. (2009) International Based ICT Adoption: Evidence from Malaysian SMEs. Industrial Management and Data Systems, 109, 224-244. https://doi.org/10.1017/CBO9780511761942

[22] Mehrtens, J., Cragg, P. and Mills, A. (2001) A Model of Internet Adoption by SMEs. Information and Management, 39, 165-176. https://doi.org/10.1017/CBO9780511761942

[23] Narver, J.C. and Slater, S.F. (1990) The Effect of Marketing Orientation on Business Profitability. International Journal, 14, 320-351.

[24] Strauss, J. and Frost, R. (2000) Internet Marketing. Prentice Hall, Inc.

[25] Singh, N., Krishnamurthy, S., Sheth, J.N. and Sharma, A. (2005) International E-Marketing. Leadership, 38, 16-22.

[26] Denning, S. (2010) Managing the Threats and Opportunities of the Open Corporation. Strategy \& Leadership, 38, 16-22.

[27] Chung, W.W., Hua, T.K., Lenny, K.S., Pavic, S., Koh, S., Simpson, M. and Padmore, J. (2007) Could E-Business Create a Competitive Advantage in UK SMEs? Benchmarking. An International Journal, 14, 320-351.

[28] Fathian, M., Akhavan, P. and Hoorali, M. (2008) E-Readiness Assessment of Non-Profit ICT SMEs in a Developing Country: The Case of Iran. Technovation, 28, 578-590. https://doi.org/10.1016/j.technovation.2008.02.002

[29] Molla, A. and Licker, P.S. (2005) E-Commerce Adoption in Developing Countries: A Model and Instrument. Information and Management, 42, 877-899. https://doi.org/10.1016/j.im.2004.09.002

[30] Davis, F.D., Bagozzi, R.P. and Warshaw, P.R. (1989) User Acceptance of Computer Technology: A Comparison of Two Theoretical Models. Management Science, 35, 982-1003. https://doi.org/10.1287/mnsc.35.8.982

[31] Mangold, W.G. and Faulds, D. (2009) Social Media: The New Hybrid Element of the Promotion Mix. Business Horizons, 52, 357-365.

https://doi.org/10.1016/j.bushor.2009.03.002

[32] Kaplan, A.M. and Haenlein, M. (2010) Users of the World, Unite! The Challenges and Opportunities of Social Media. Business Horizons, 53, 59-68. https://doi.org/10.1016/j.bushor.2009.09.003

[33] Chua, A.Y.K. and Banerjee, S. (2013) Customer Knowledge Management via Social Media: The Opportunities and Issues. International Marketing Review, 22, 611-622.

[34] Clark, M. and Melancon, J. (2013) The Influence of Social Media Investment on Relational Case of Starbucks. Journal of Knowledge Management, 17, 237-249.

[35] Baird, C.H. and Parasnis, G. (2011) From Social Media to Social Customer Relationship Management. Strategy and Leadership, 39, 30-37. https://doi.org/10.1108/10878571111161507

[36] Rieck, D. (2010) B2B vs. Consumer Marketing: 5 Key Differences. Business-to-Business Markets. Industrial Marketing Management, 39, 1097-1102.

[37] Wicks, D. (2015) Role of Social Media Marketing in Business. Industry Dive Digital Media Company, New York.

[38] Smits, M. and Mogos, S. (2013) The Impact of Social Media on Business Performance. Completed Research, 1-13. 
[39] Rindell, A. and Strandvik, T. (2010) Corporate Brand Evolution: Corporate Brand Images Evolving in Consumers' Everyday Life. European Business Review, 22, 276-286. https://doi.org/10.1108/09555341011040976

[40] Schulze, H. (2013) B2B Lead Generation Marketing Trends. Proceedings of the 21 st European Conference on Information Systems.

[41] Fillis, I., Johansson, U. and Wagner, B. (2003) A Conceptualization of the Opportunities and Barriers to E-Business Development in the Smaller Firm. Journal of Small Business and Enterprise Development, 10, 336-344. https://doi.org/10.1108/14626000310489808

[42] Zachary, R., David, T., Kim, C. and Sarah, T. (2013) The Social Behaviours of Your B2B Customers.

http://www.forrester.com/The+Social+Behaviours+Of+Your+B2B+Customers/fullt ext/-/E-RES99721

[43] Kiron, D. (2012) How IBM Builds Vibrant Social Communities. http://sloanreview.mit.edu/article/how-ibm-builds-vibrant-social-communities/

[44] Jussila, J.J., Karkkainen, H. and Aramo-Immonen, H. (2014) Social Media Utilization in Business-to-Business Markets. Ekonomska Istrazivanja, 25, 364-388.

[45] Ivey, J. (2014) Customer Relationship Management Software User View. http://www.softwareadvice.com/crm/userview/report-2014/

[46] Ahiauzu, A. (2006) Advance Research Methods in the Management Sciences Port Harcourt. Lecture Notes PhD Class Rivers State University of Science and Technology.

[47] hiauzu, A.I. (2004) Advanced Research Methods. Being an Unpublished Seminar Paper of the Centre for Management Research and Training (CIMRAT) Port Harcourt.

[48] Trochim, W. (2006) The Research Methods Knowledge Base. Atomic Dog Pub. 2013, Cincinnati. 